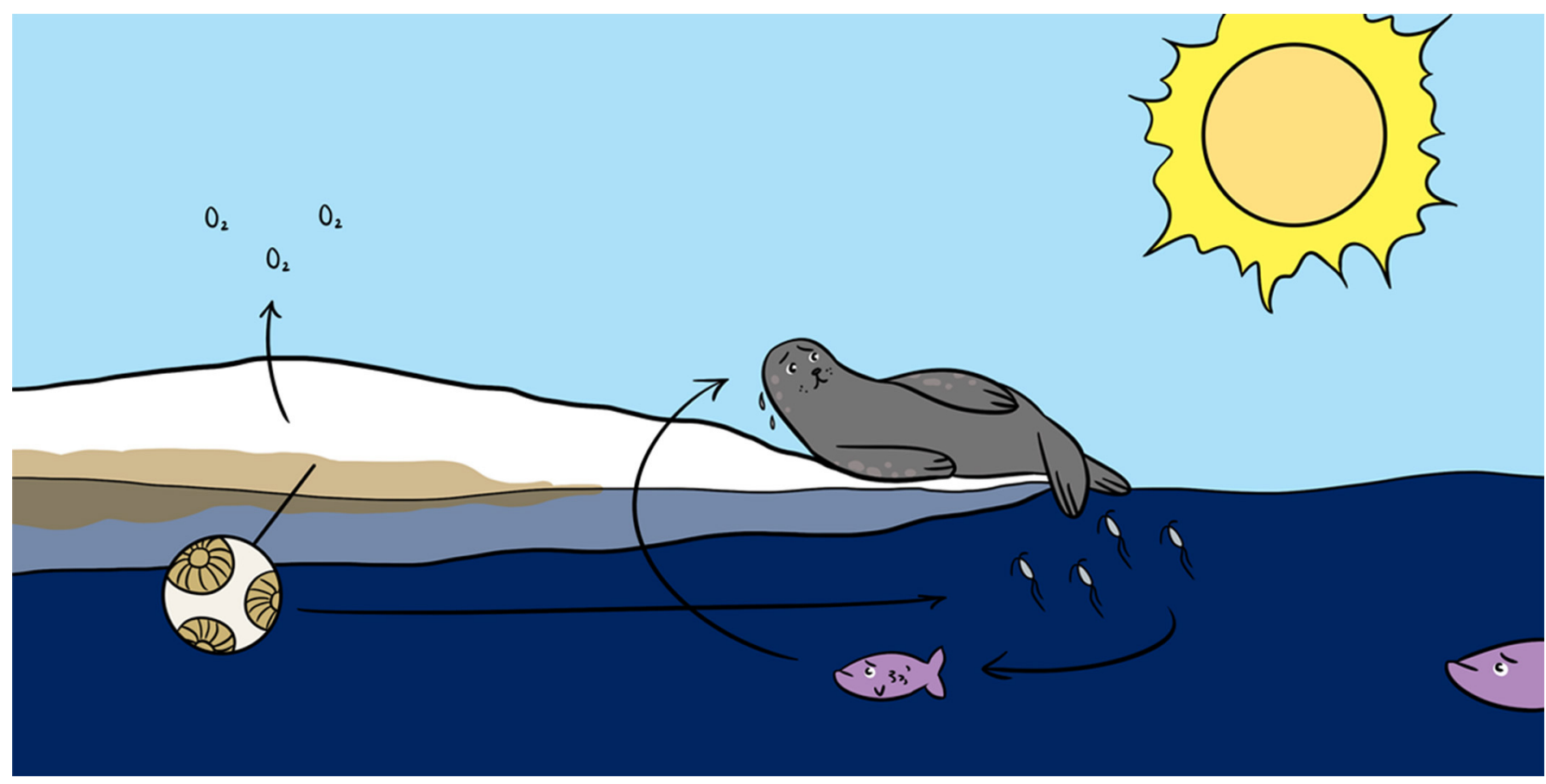

\title{
THE BOTTOM OF THE ARCTIC'S FOOD WEB IS OF TOP IMPORTANCE
}

\author{
Alexander G. Hayward ${ }^{1,2^{*}}$ and Jordan Jack Grigor ${ }^{3 *}$ \\ ${ }^{1}$ Marine Biogeochemistry Department, National Institute of Water and Atmospheric Research, Wellington, New Zealand \\ ${ }^{2}$ Department of Marine Sciences, University of Otago, Dunedin, New Zealand \\ ${ }^{3}$ Scottish Association for Marine Science, Oban, United Kingdom
}

YOUNG REVIEWERS:

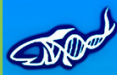

FDR-HB_PERU

iGEM TEAM

AGES: $14-17$
As our planet's climate warms, its most rapidly changing region is the Arctic Ocean and surrounding seas. Warming causes many changes, including the melting of sea ice and a decline in the amount of water that is covered by ice. These changes impact organisms at every level of the food web. In this article, we explain how changes in temperature affect the quality of food available for animals that live in the Arctic. We focus on changes near the bottom of the food web, involving tiny plants that dwell inside and below sea ice, and tiny animals that drift in the Arctic seas. Shifts in the abundance and quality of the smallest organisms in the Arctic Ocean affect larger organisms, such as polar bears and whales. Changes at the base of the food web must be considered if we want to protect the creatures that call the Arctic home. 


\section{HOW A CHANGING CLIMATE AFFECTS THE ARCTIC}

Since the start of the Industrial Revolution, over 200 years ago, our planet's climate has changed drastically. Temperatures have soared at a faster rate than any other time in the past 65 million years! At the most northern and southern tips of our planet are the polar regions, the Arctic and the Antarctic. These are the coldest regions of Earth, where temperatures average well below $0^{\circ} \mathrm{C}$. In winter, the top layer of the ocean freezes, creating what is called sea ice. Sea ice can range from paper thin ice, which melts very quickly, to incredibly thick ice that reaches heights of $3 \mathrm{~m}$ and can survive for many years. Sea ice has a cooling effect on the climate, acting as a refrigerator and keeping the rest of the planet at habitable temperatures.

As the temperature of our planet has increased, the environment has reacted in unique and alarming ways. In polar regions, large areas of sea ice are melting. The once snowy, white polar regions are being transformed into large areas of blue, open ocean. The warming of the polar regions has created a lot of questions that need answering. So, let us shed some light on how rising temperatures could affect the Arctic's marine ecosystem.

\section{PHYTOPLANKTON}

A drifting plant that performs photosynthesis.

\section{PHOTOSYNTHESIS}

A process in which plants use the sun's energy to convert carbon dioxide and water to oxygen and sugar.

\section{BIOMASS}

The total weight of an organism, or group of organisms in a specific region.

1 https://www. changingarctic-ocean. ac.uk/

\section{DIATOM}

A large type of phytoplankton that is an important food source for zooplankton

\section{WHY ARE PHYTOPLANKTON SO IMPORTANT?}

At the base of the marine ecosystem, we find very small, but very important, plant-like creatures that drift in all seas. These creatures are called phytoplankton. Due to the microscopic size of phytoplankton, they are measured on the scale of microns ( $\mu \mathrm{m})$. One micron is 10,000 times smaller than a centimeter!

Phytoplankton typically live in what we call the euphotic zone, simply put, the depths where there is enough light for their photosynthesis. Through photosynthesis, they take in carbon dioxide $\left(\mathrm{CO}_{2}\right)$ from the atmosphere and produce oxygen, just like plants on land. Together, all the phytoplankton in the world's oceans produce half of the Earth's oxygen. This is an immense amount of oxygen considering that phytoplankton make up $<1 \%$ of the world's plant biomass [1]! In comparison, large plants like trees make up around $70 \%$ of global plant biomass yet produce about the same amount of oxygen as microscopic phytoplankton ${ }^{1}$. To demonstrate just how hardy phytoplankton are, it is worthwhile to note that they have been around a pretty long time. The first sign of phytoplankton was preserved in rocks from western Australia around 3.5 billion years ago!

Diatoms are the largest phytoplankton in our oceans (Figure 1). They can be circular or elongated plants and are responsible for almost $20 \%$ of the Earth's photosynthesis. Though diatoms primarily live in the open ocean, they also thrive in bizarre places. Large masses of diatoms have been found within the sea ice of both polar regions, dwelling 
Figure 1

A circular diatom (left) ${ }^{2}$ and a phytoplankton community (right) ${ }^{3}$

Scale bars are

approximations of size.

2 https://www.gercekbili m.com/inanilmaz-elekt ron-mikroskopu-fotogr aflari-2/diatom-sem/

3 https://ethz.ch/de/new s-und-veranstaltungen/ eth-news/news/2019/ 05/weltweite-plankton verteilung.html

\section{ZOOPLANKTON}

A drifting animal unable to swim against an ocean current.

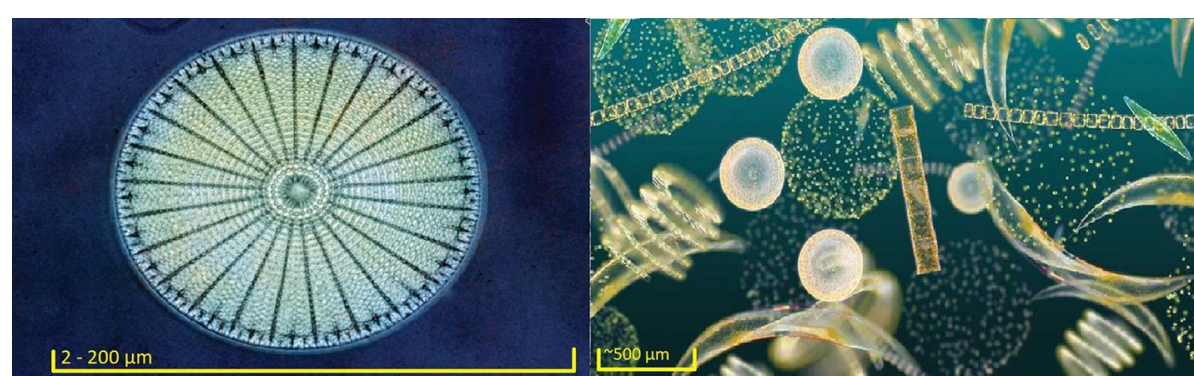

Figure 1

inside salty, liquid, ice channels that have enough nutrients and light for them to perform photosynthesis. When diatoms are found in ice they are no longer classified as phytoplankton. As they are fixed in one place and do not drift we call them ice-dwelling algae or simply ice algae. They are often trapped in the ice as the top layer of the ocean starts to freeze. To find ice algae, ice cores roughly $10 \mathrm{~cm}$ in diameter are drilled out of the ice. Figure 2 shows the bottom of an ice core that has an abundance of algae inside.

\section{WHAT EATS PHYTOPLANKTON?}

Zooplankton are the "middlemen" of the Arctic, performing the essential role of distributing nutrients to creatures throughout the food web as they are eaten by larger predators (Figure 3). At some point in their lives, crabs, fish, and squid are all ocean drifters, and therefore termed zooplankton. Diatoms are a major food source for many zooplankton, because they contain many nutrients that give zooplankton the energy and raw materials to carry out activities, such as growing and reproducing.

As sea ice melts in summer, nutrients stored in the ice are released back into the ocean. Light also becomes more available because there is less sea ice to reflect the light back into the atmosphere. These spring changes favor phytoplankton, zooplankton, and everything that consumes these bottom-of-the-food-web residents. Since zooplankton eat diatoms, the zooplankton themselves become nutritious for larger animals, such as fish, seabirds, and whales [2]. If zooplankton were not present, the rest of the ecosystem, including humans, would face a great loss of food. Humans in Inuit communities have relied on fish (zooplankton predators) and seals (fish predators) in the Arctic for over 10,000 years!

There is a dirty aspect of zooplankton that is particularly importanttheir poo. When zooplankton excrete their bodily waste, it becomes a food source for many other creatures. If it does not get eaten, it can end up in the seabed where it stores carbon for millions of 
Figure 2

An ice core showing sea ice algae (brown layer inside the ice), including diatoms, dwelling within the bottom $10 \mathrm{~cm}$ of the ice $^{4}$.

4 http://www.antarctica. gov.au/science/climate - processes-and-chang e/oceans-and-marineice-in-the-southern-he misphere/measuringalgae-in-the-fast-ice -research-blog/sea-ice -algae-project-blog/bl og-8-first-ice-algae

\section{COPEPODS}

A type of zooplankton with oar shaped feet. A very abundant type of copepod is called Calanus.

\section{CALANUS}

Some of the most abundant and nutritious copepods in the Arctic Ocean belong to this group.

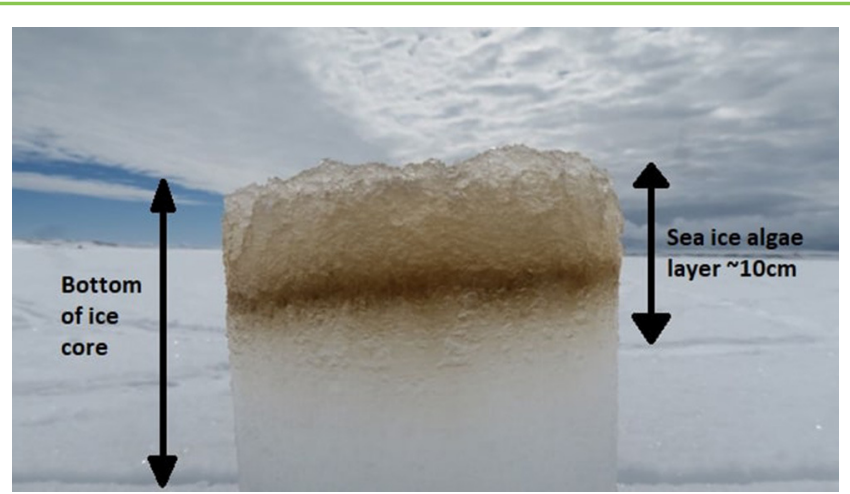

Figure 2

years, slowing down the process of climate change, and keeping our planet cool.

One group of zooplankton found in marine ecosystems worldwide is particularly noteworthy. The copepods were given their name due to their "pods" (or feet), which are shaped like the oars used for rowing a boat. Their oar-like feet (Figure 4) help to give these microscopic animals superhero powers! Copepods could win prizes for having some of the most outstanding features in the animal kingdom. Copepods are the strongest animal, the fastest jumpers, and may be the most numerous type of animal on the planet! The favorite food of many copepods is phytoplankton, which must live near the ocean surface where there is enough sunlight for photosynthesis. Feeding on phytoplankton is good, but not always safe; fish, birds, and other predators also hunt in the well-lit surface water, and they are waiting for copepods to make a mistake. Every day, copepods deal with the threat of predators by only entering the shallow water at night, when there is no light. After eating, copepods quickly migrate down to deeper, darker waters before shallow-water predators can see them. This daily migration of copepods and other zooplankton is the largest migration of biomass on the planet, a humongous daily movement spanning depth of tens, hundreds, or thousands of meters.

Some of the most abundant copepods in the Arctic Ocean are members of a group called Calanus. Packed with nutritious fats after intense spring and summer feeding, the Calanus copepods are so nutritious that some seabirds, fish, and whales travel massive distances across the oceans every year to gorge on them, typically in spring and summer. When most of the phytoplankton and zooplankton have been eaten, many of the birds, fish, and mammals leave the Arctic, to return the following year (but not all). 
Figure 3

The Arctic's marine food web [2].

Phytoplankton and ice algae are eaten by zooplankton, and in turn, zooplankton are eaten by polar cod, seabirds, and the bowhead whales. This shows how both phytoplankton and zooplankton are an incredibly important food supply to the rest of the Arctic's ecosystem.

\section{BLOOM}

Rapid growth of algae or phytoplankton.

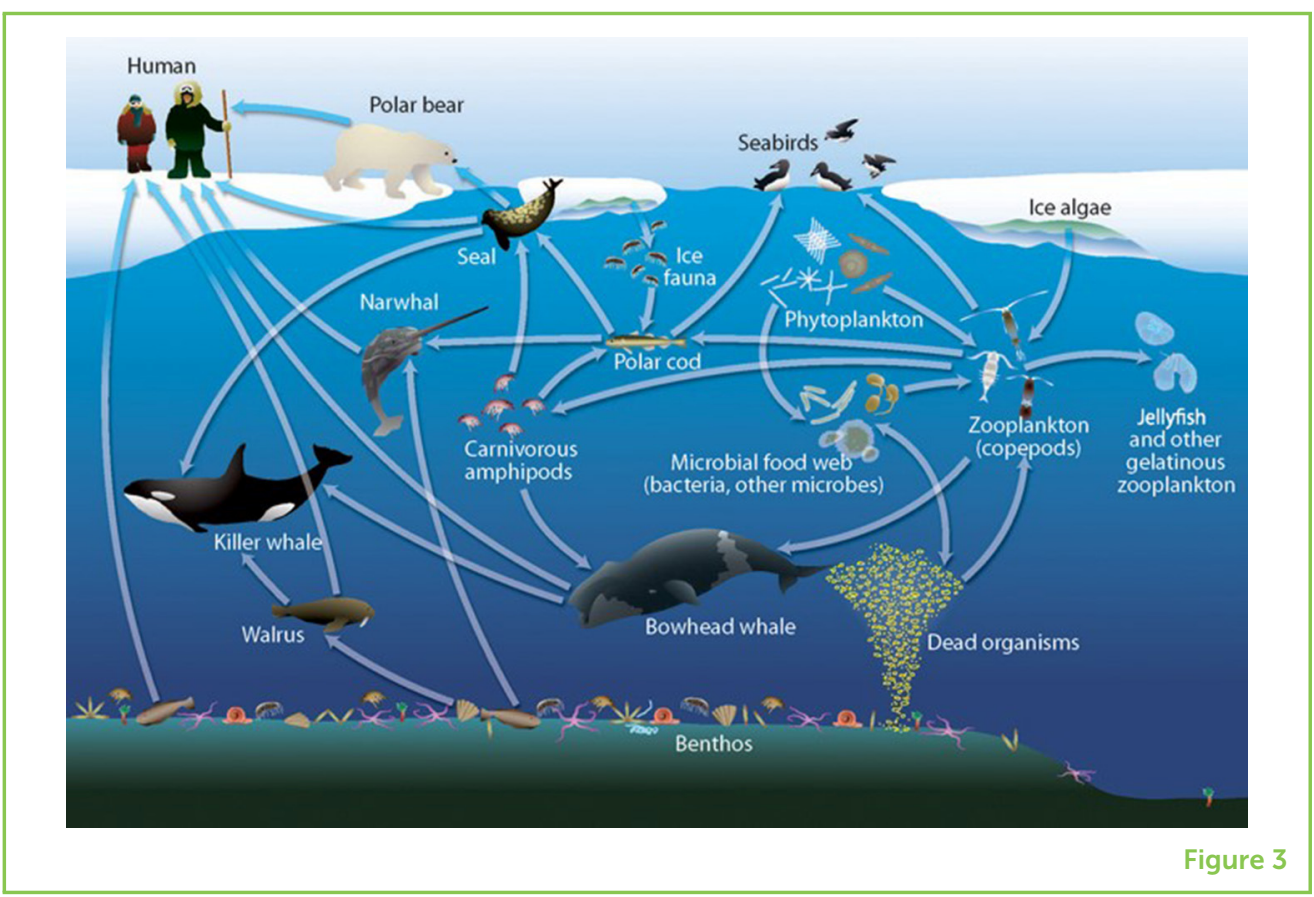

\section{THE DARKNESS}

The dark months of winter may not be the best time to be an herbivore dependent solely on photosynthesising plants for survival! Some copepods become omnivores in the winter, while others stop eating altogether and enter hibernation in safe waters far below the sea ice. Intense feeding during peak phytoplankton abundance is crucial for building the necessary fat stores to hibernate during winter. Copepods can look very different in February (after a winter of hibernation and starvation) compared to June (after feeding). In the Arctic, waking up before the phytoplankton bloom can be beneficial to copepods. It allows them to feed on diatoms that hang and fall off the bottom the sea ice in spring. Following months of hibernation, an individual Calanus typically appears skinny, with limited fat reserves. It is only after feeding in spring and summer that a Calanus copepod can replenish its fat stores to their former glory (Figure 4) [3]! After their return to algae-rich surface waters in the spring, many successful copepods reproduce during the spring ice algal bloom, allowing their offspring to hatch during the phytoplankton bloom that occurs below the ice a few months later [3]. This may be essential for their offspring to survive.

\section{THE FUTURE}

Researchers believe that if Calanus copepods failed to eat ice algae, the size of the copepod population could be drastically reduced. As sea ice declines due to climate change, this important food source for copepods is removed. Over long time scales, sea ice loss and other factors could decrease the availability of nutrients for the 
Figure 4

Calanus copepods sampled in February (left) and June (right). Though the lengths of the two copepods are relatively similar ( 4.4 and $4.8 \mathrm{~mm}$ ), the February copepod is smaller overall than the June copepod, and the February animal, which is approaching the end of hibernation, also contains less fat in its oil sac (2019).

5 https://www.changing -arctic-ocean.ac.uk/ project/eco-light/

6 https://www.changing -arctic-ocean.ac.uk/ project/chase/

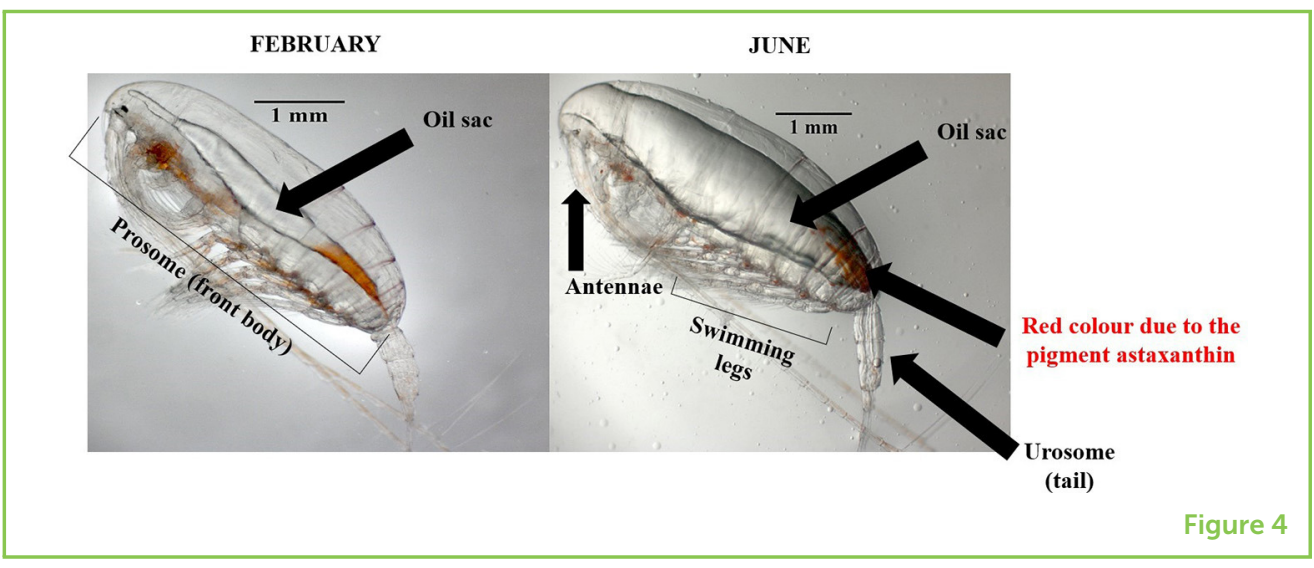

phytoplankton that are trying to grow below the ice [4]. This decrease of food for phytoplankton could mean that smaller phytoplankton would become more numerous than bigger, more nutritious diatoms. So, instead of having an abundance of high-quality food like large diatoms, copepods in a warmer, ice-free Arctic might be forced to eat less nutritious, smaller phytoplankton. Scientists are already seeing smaller-sized organisms in both the copepod and phytoplankton communities [5].

\section{PROJECTED CHANGES IN THE ARCTIC AND WHAT WE CAN DO TO HELP}

As the Arctic region changes, it is likely that we could see food stocks, such as diatoms and other phytoplankton decline, while also becoming smaller and less nutritious. Changes in the lowest part of the food web can have immense consequences for larger animals. Extinction of species at the bottom of the food web can be terrible news for specialized predators that have evolved to eat them. Changes in the amount and type of plankton affect humans and animals in many direct and indirect ways, ranging from changes in air quality, to how we interact with the environment and its resources. With less phytoplankton in the Arctic, $\mathrm{CO}_{2}$ concentrations in the atmosphere would increase causing our planet to continue warming.

As a society, we need to be more aware of the fact that our activities at home, work, or school can all affect ecosystems in places that are far away from us. Small changes, such as walking or cycling instead of driving can drastically help to limit $\mathrm{CO}_{2}$ emissions. Research programs like the Changing Arctic Ocean ${ }^{1}$, based in the UK, are providing governments and the public with the most up-to-date information on biological changes in the Arctic. Two groups from Changing Arctic Ocean have collaborated on writing this manuscript, and we have additional resources available if you would like to learn more 5,6 . 


\section{REFERENCES}

1. Bar-On, Y. M., Phillips, R., and Milo, R. 2018. The biomass distribution on Earth. Proc. Natl. Acad. Sci. U.S.A. 115:6506-11. doi: 10.1073/pnas.1711842115

2. Darnis, G., Robert, D., Pomerleau, C., Link, H., Archambault, P., Nelson, R. J., et al. 2012. Current state and trends in Canadian Arctic marine ecosystems: II. Heterotrophic food web, pelagic-benthic coupling, and biodiversity. Clim. Change 115:179-205. doi: 10.1007/s10584-012-0483-8

3. Leu, E., Søreide, J. E., Hessen, D. O., Falk-Petersen, S., and Bergebe, J. 2011. Consequences of changing sea-ice cover for primary and secondary producers in the European Arctic shelf seas: timing, quantity, and quality. Prog. Oceanogr. 90:18-32. doi: 10.1016/j.pocean.2011.02.004

4. Li, W. K. W., McLaughlin, F. A., Lovejoy, C., and Carmack, E. C. 2009. Smallest algae thrive as the Arctic Ocean freshens. Science 326:539. doi: 10.1126/science.1179798

5. Falk-Petersen, S., Timofeev, S. F., Pavlov, V., and Sargent, J. R. 2007. "Climate variability and possible effects on Arctic food chains. The role of Calanus," in Arctic-Alpine Ecosystems and People in a Changing Environment, eds J. B. Ørbæk, T. Tombre, R. Kallenborn, E. N. Hegseth, S. Falk-Petersen, and A. H. Hoel (Berlin: Springer). p. 147-66.

SUBMITTED: 29 November 2019; ACCEPTED: 06 August 2020; PUBLISHED ONLINE: 17 September 2020.

EDITED BY: Roxana Suehring, Stockholm University, Sweden

CITATION: Hayward AG and Grigor JJ (2020) The Bottom of the Arctic's Food Web Is of Top Importance. Front. Young Minds 8:122. doi: 10.3389/frym.2020.00122

CONFLICT OF INTEREST: The authors declare that the research was conducted in the absence of any commercial or financial relationships that could be construed as a potential conflict of interest.

COPYRIGHT @ 2020 Hayward and Grigor. This is an open-access article distributed under the terms of the Creative Commons Attribution License (CC BY). The use, distribution or reproduction in other forums is permitted, provided the original author(s) and the copyright owner(s) are credited and that the original publication in this journal is cited, in accordance with accepted academic practice. No use, distribution or reproduction is permitted which does not comply with these terms.

\section{YOUNG REVIEWERS}

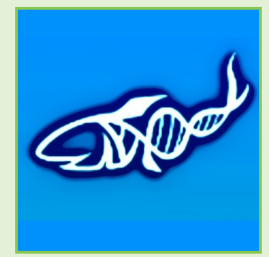

\section{FDR-HB_PERU iGEM TEAM, AGES: 14-17}

We are a synthetic biology team with the international Genetically Engineered Machine (iGEM) in Lima, Peru. We are the only high school team in Latin America and are proud of our work with creating a detector for cadmium using bacteria. Most of us are second language learners and the age range of our group is 14-17 years old. We love GMOs! 


\section{AUTHORS}

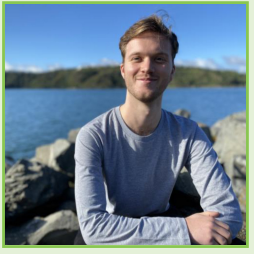

\section{ALEXANDER G. HAYWARD}

Alexander G. Hayward is a Ph.D. student working at NIWA and the University of Otago in New Zealand. He is investigating how the function and composition of Antarctica's microbial community (phytoplankton, micro-zooplankton, and sea ice algae) is changing under environmental stressors resulting from climate change. Prior to this, Alexander's work focused on measuring the productivity and biomass of sea-ice in the Arctic Ocean. *alexander.hayward@niwa.co.nz

\section{JORDAN JACK GRIGOR}

Dr. Jordan Grigor is a marine biologist with several years of focusing on the ecology of small animals, such as copepods and arrow worms. He works within the Arctic, where many animals are being affected by rapid changes in climate. He has revealed information about little known species (e.g., https://www.researchgate.net/project/Ecology-of-chaetognaths-arrow-worms-in -Arctic-waters), showing that arrow worms feed on diatoms and copepods. Now working on the CHASE project (https://www.changing-arctic-ocean.ac.uk/ project/chase/) at the Scottish Association for Marine Science, he is trying to understand the influence of environment and genetics on swimming behavior in copepods. *jordan.grigor@sams.ac.uk 